$12-31-2020$

\title{
Community engagement in COVID-19 responses: Evidence from qualitative interface with community opinion leaders in Enugu,
}

\section{Nigeria}

\author{
Prince Agwu \\ Department of Social Work, University of Nigeria, Nsukka, Nigeria and Health Policy Research Group, \\ College of Medicine, University of Nigeria Enugu Campus, Enugu, Nigeria, prince.agwu@unn.edu.ng \\ Chinweoke Methodius Ugwu \\ Department of Social Work, University of Nigeria, Nsukka, Nigeria, chinweokemetho@gmail.com
}

See next page for additional authors

Follow this and additional works at: https://scholarhub.ui.ac.id/ajce

Part of the Public Health Commons, and the Social and Behavioral Sciences Commons

\section{Recommended Citation}

Agwu, Prince; Ugwu, Chinweoke Methodius; and Eke, Chidera Florence (2020). Community engagement in COVID-19 responses: Evidence from qualitative interface with community opinion leaders in Enugu, Nigeria. ASEAN Journal of Community Engagement, 4(2), 416-434.

Available at: https://doi.org/10.7454/ajce.v4i2.1115

Creative Commons License

\section{(c) (i) ()}

This work is licensed under a Creative Commons Attribution-Share Alike 4.0 License.

This Research Article is brought to you for free and open access by the Universitas Indonesia at ASEAN Journal of Community Engagement. It has been accepted for inclusion in ASEAN Journal of Community Engagement. 


\title{
Community engagement in COVID-19 responses: Evidence from qualitative interface with community opinion leaders in Enugu, Nigeria
}

\author{
Prince Agwu ${ }^{a b}$, Chinweoke Methodius Ugwua ${ }^{a}$, Chidera Florence Eke ${ }^{c}$ \\ a Department of Social Work, University of Nigeria, Nsukka, Nigeria \\ ${ }^{b}$ Health Policy Research Group, College of Medicine, University of Nigeria Enugu Campus, Enugu, Nigeria \\ ${ }^{c}$ FHI360/AHNi, Uyo, Nigeria
}

Received: November 4th 2020 || Revised: November 23 ${ }^{\text {rd }}, 2020$ || Accepted: December 27th, 2020

\begin{abstract}
Successful stories of community engagement existed during the Ebola disease outbreak in Liberia, indicating that a combination of government and community efforts are needed in addressing pandemics or epidemics. However, for communities to rise to the challenge of containing and combatting the spread of any disease, they must be communicated most effectively and supported by the government. Therefore, our study investigates how applicable successful community engagement has been in the charge against the Coronavirus disease 2019 (COVID-19) in Nigeria. Through telephone interviews, we sourced data from 12 community opinion leaders in Enugu State, Nigeria. After conducting a thematic analysis of responses, we discovered that the Nigerian government had several gaps in engaging the grassroots in the charge against COVID-19. These gaps comprise the lack of effective inclusion strategies of rural communities and the uneducated, weak accountability, poor database of citizens, weak accountability of security agents, weak primary healthcare system, and the dearth of grassroots-targeted communication. The effects of these gaps majorly manifested in the compromise and disregard of safety measures, which most likely put Nigeria at risk of increased cases of COVID-19 or poor response to disease outbreaks in the future. We concluded that the government must improve its accountability records while effectively interfacing with the grassroots during disease outbreaks and co-producing strategies.
\end{abstract}

Keywords: COVID-19; pandemics; community engagement; community participation; co-production.

\section{Introduction}

The spread of the Coronavirus disease 2019 (COVID-19) across the globe has remained unprecedented with several devastating health and socioeconomic consequences (European Center for Disease Prevention and Control, 2020). The spontaneity and somewhat uncontrolled spread of the disease seem to have exposed the weak preparedness of the world in containing global pandemics (Kavanagh et al., 2020). The pandemic has reinforced the need to address public health concerns from a multidisciplinary perspective, and from a community lens. The several guidelines put in place to contain COVID-19 are mostly behavioral, such as washing hands, avoiding crowded places, wearing facemasks, maintaining physical distancing, reporting

\footnotetext{
*Correspondence Author: prince.agwu@unn.edu.ng
} 
Prince Agwu, Chinweoke Methodius Ugwu, Chidera Florence Eke | ASEAN Journal of Community Engagement | Volume 4, Number 2, 2020

to a health facility when ill, among others. To achieve compliance with these behavioural protocols to stem the spread of the virus, the cooperation of community members is needed. This is why grassroots-supported approach to public health issues is reckoned to be vital in the context of disease outbreaks (van Niekerk et al., 2020).

During the fight against the Ebola epidemic in Liberia, communities were considered active participants (Abramowitz et al., 2015). The gesture led to increased trust in health authorities and speedier facilitation of health system response efforts that successfully contained the spread of the disease (Barker et al., 2020). In Ghana, details of how community opinion leaders were active in scaling up public health education on COVID-19 existed, using local languages and putting community-inspired sanctions in place against defaulters. The active participation of the opinion leaders in Ghanaian communities inspired a percentage acceptance of test results from 15\% to $90 \%$ (African Field Epidemiology Network [AFENET], 2020). Similar shreds of evidence of community participation were found in China, where governance structures in communities were strengthened to regulate behaviours of community members against COVID-19 (Zhu \& Cai, 2020). Also. in India social workers were charged to go into the interiors to engage community leaders and members in the responsibility of staying safe and shunning erroneous beliefs concerning the virus (The Economic Times, 2020). These instances as listed, evidence the need to strengthen community structures during public health emergencies.

With the spread of the virus in Nigeria that now marches above 60,000 cases at the time of writing, emanating from testing only $0.2 \%$ of 200 million residents in the country (Nigeria Center for Disease Control, 2020), the approach that the Nigerian government has taken must be examined to curb the spread of the virus must be examined. Emphasis must be on approaches that entail citizens taking responsibility to stay safe and healthy, given the consequences of the poor rate of testing and the resilience to withstand the socioeconomic shock resulting from the pandemic.

Community engagement is a proven strategy of co-producing knowledge, capacities, and actions to address issues affecting the well-being of people (Enwereji \& Ezema, 2020; National Institutes of Health, 2011). The strategy is employed by governments, organizations, and academics as a way of having the people understand their conditions and cultivate the responsibility of addressing them without the need to be compelled. Community engagement is known to public health and is proven to be successful in producing effective responses to public health emergencies, inclusive of pandemics (O'Mara-Eves et al., 2015; Ramsbottom et al., 
Prince Agwu, Chinweoke Methodius Ugwu, Chidera Florence Eke | ASEAN Journal of Community Engagement | Volume 4, Number 2, 2020

2017). Community engagement is also stated to be critical in the production of effective health policies, indicating that community engagement can improve governance in health systems because it is bound to be in tune with the needs and expectations of the grassroots (O'MaraEves et al., 2012). Therefore, health policies, especially public health policies and programmes that make no attempt to galvanize participation of the grassroots, paying attention to their peculiarities, might run the risk of not achieving the desired success. The idea is that communities would always desire a sense of voice and ownership of whatsoever that is brought to them. The aim is to ensure that they carry on with the ideas even when those that originally brought the ideas to them are no more.

Professions dealing with community engagement are yet to gain professional status in Nigeria. One good example is the social work profession whose clamor for professionalization suffers many political setbacks (Agwu et al., 2020; Ogbonna, 2018). Recent social work-focused studies on COVID-19 lament the gaps in grassroots engagements and interventions to stem the spread and further complain about the preponderant emphasis of responses to the virus on hospital/laboratory-based services (Nnama-Okechukwu et al., 2020; Onalu et al., 2020). Although engagements with some community opinion leaders in Nigeria are documented, they are the most found not to have yielded improvement in safety behaviours against the virus (Dixit et al., 2020; Okwor, 2020). This means that the way and manner communities are engaged over any issue will determine their reactions. Engaging a community by communicating an already developed strategy to contain a public health emergency differs from when they are engaged to help offer ideas and insights to co-produce strategies that can work for them. In the former, community members are most likely to feel compelled, and might be forced to rebel. Whereas, in the latter, they develop voice and ownership and are appreciative of strategies that must have considered their peculiarities.

At a certain time, the Presidential Task Force on COVID-19 in Nigeria lamented abysmally the low cooperation of Nigerians toward staying safe and insinuated the possibility of a lockdown in the future (Ogundipe \& Olawale, 2020). First, the earlier lockdown was a topbottom approach, and when it was as though it will be extended, most Nigerians threatened to defy the order (Onyishi et al., 2020). The message Nigerians tried to pass was that the lockdown strategy seems not to accommodate their socioeconomic peculiarities, and there was the need for government to dialogue with them on what could possibly work to contain the spread of the 
Prince Agwu, Chinweoke Methodius Ugwu, Chidera Florence Eke | ASEAN Journal of Community Engagement | Volume 4, Number 2, 2020

virus. Some scholars have argued that lockdowns in Nigeria is not context-specific to the culture of survival, interaction, and orientation of Nigerian communities (Agwu, 2020; Nelson, 2020).

An added pain to the lockdown were the many irregularities of some security personnel. Members of some security outfits in Nigeria that were charged with enforcing compliance were implicated in deviant acts, such as bribery and extortion which also led to the further spread of the virus. At the onset of the pandemic in Nigeria the government placed a ban on inter-state travels. Unfortunately, CLEEN Foundation (2020) reported that such travels continued, so far as commuters would have the money to pay bribes to the security personnel at the borders. This shows that even the supposed enforcers of the law could not efficiently achieve compliance with safety protocols. There were even reports of brutality against citizens to enforce compliance with the safety protocols, yet the results were suboptimal (CLEEN Foundation, 2020). Thus, with recorded successes of community engagement during the Ebola outbreak, and other public health emergencies, there is the need to scale up community-focused governance (a leadership style inviting grassroots to co-create knowledge and take charge of their implementation and enforcement) in addressing disease outbreaks (Abramowitz et al., 2015; Ebenso \& Otu, 2020; Onyishi et al., 2020).

Following the backdrop, our article examines the involvement of the grassroots in addressing the COVID-19 pandemic in Nigeria. Experiences and insights from community leaders are sought, as they are deemed to be the gatekeepers of communities. Thus, our article contributes to the growing body of literature on the COVID-19 pandemic response in Nigeria by examining the lived experiences of grassroots stakeholders on the extent of their involvement in containing the disease outbreak. The study hopes to particularly offer the need to build strong community-focused governance to drive public health decisions in Nigeria, going forward.

\subsection{Conceptual framework}

After gleaning literature on community engagement, we designed the Process-ParticipationResponse-and-Results (PPRR) framework and adopted it to explain how governance can translate into responsibilities that can scale up the safety of citizens during pandemics. We argued that results, which in this case refer to compliance with efforts that should curb the spread of the virus, are only consequences of governance expressed through targeted efforts made at galvanizing the grassroots. The implication is that if persons at the grassroots are not 
Prince Agwu, Chinweoke Methodius Ugwu, Chidera Florence Eke | ASEAN Journal of Community Engagement | Volume 4, Number 2, 2020

well governed, such that they become involved in the job of staying safe by themselves, then the results can be devastating. Therefore, the PPRR model is focused on emphasizing the need for government actors to work with community members, so that they could take up the responsibility of complying with safety protocols against COVID-19. This also helps to ease government's burden, especially with regard to enforcing compliance.

The PPRR model takes into consideration the recent predictions of emerging and devastating trends of transmission of COVID-19 from urban to rural areas in Nigeria (ACAPS, 2020). This is because, rural areas, which dominate the grassroots, and are known for having people with poor education, weak access to information, a weak healthcare system, and lacking financial resources, and can thus be regarded as a vulnerable group. Notwithstanding the need for community engagement across Nigeria to intensify efforts in curbing the spread of COVID19 , the rural areas with the least informational, financial, and health resources should form a prime target for the adoption of the PPRR model in community engagement. Figure 1 shows how the model can be applied, as well as how community-focused governance can impact responses to stay safe during disease outbreaks.

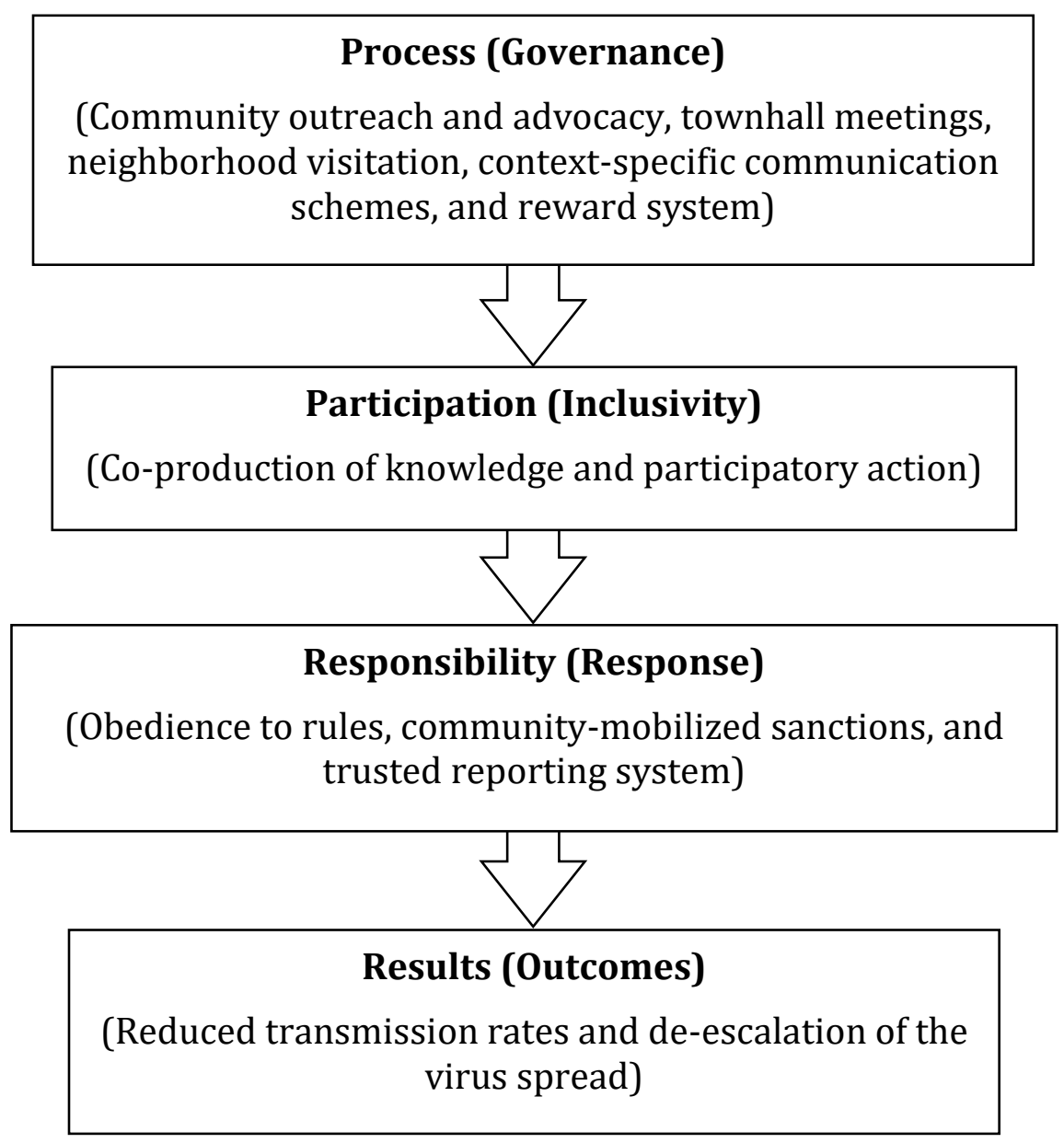

Fg. 1 PPRR community engagement model designed by authors. 
Prince Agwu, Chinweoke Methodius Ugwu, Chidera Florence Eke | ASEAN Journal of Community Engagement | Volume 4, Number 2, 2020

\section{Methods}

The study was conducted in Enugu State, which is in the south-eastern part of Nigeria. Enugu State has recorded over 1,000 COVID-19 cases as of writing and has the highest number of confirmed COVID-19 cases in the southeast (NCDC, 2020). The state is dominated by Christians and the Igbo ethnic group. We drew respondents from two local government areas (LGAs), namely, Enugu North and Nsukka LGAs. Enugu North houses the famous Enugu City, which is the seat of government; meanwhile, Nsukka houses a good number of rural locations, even though a part of it is increasingly becoming urbanized. Respondents from these two locations were helpful with the kind of information we needed concerning the experience of community engagement in urban and rural settings.

The respondents were purposively selected based on the quality of the information we needed. Therefore, we only selected opinion leaders, such as heads of trade groups, traditional rulers, youth leaders, administrators at local governments, and community health extension workers (CHEWs). A total of 12 respondents (six from each area) were selected and interviewed in-depth. The interviews were conducted over android phones that had the callrecording feature. We resorted to telephone interviews owing to physical distancing protocol and the need to keep safe while doing qualitative research. Each interview lasted for not more than an hour to avoid causing fatigue to respondents and to manage our lean resources. Respondents were booked ahead of time, and interviews were only conducted at their convenience. Steps were taken to ensure ethical compliance by paying attention to anonymizing identities, full disclosure of research use, informed consent before recording, and confidentiality.

After voice recording, we transcribed the responses in English language and coded the transcripts. In the process of transcription, we were careful to ensure that meanings were not lost by double-checking each transcript while concurrently replaying the voice recording. Following phenomenology in qualitative research, we coded responses in themes (Creswell, 2013), which reflect the questions we asked. Three themes were generated: (a) Extent of involvement of the grassroots by the government, (b) Mode of communication and efficacy, (c) What can be done further?

After the categorization of responses in themes, the analysis spreadsheet was vetted by the authors and two-independent peers in line with peer debriefing and observer triangulation, both of which deepen rigor in qualitative research (Padgett, 2008). Suggestions were made on 
Prince Agwu, Chinweoke Methodius Ugwu, Chidera Florence Eke | ASEAN Journal of Community Engagement | Volume 4, Number 2, 2020

moving some of the quotes to the best theme that will be appropriate for them. The suggestions were considered. Table 1 shows the sociodemographic distribution of the respondents.

Table 1. Sociodemographic distribution of respondents

\begin{tabular}{lll}
\hline \multicolumn{1}{c}{ Sociodemographic } & Frequency & Percentage frequency (\%) \\
\hline Gender & 10 & 83.3 \\
Male & 2 & 16.7 \\
Female & $\mathbf{1 2}$ & $\mathbf{1 0 0}$ \\
Total & & \\
Age & 4 & 33.3 \\
$\leq 30$ years & 8 & 66.7 \\
$>$ 30 years & $\mathbf{1 2}$ & $\mathbf{1 0 0}$ \\
Total & & \\
Position & 2 & 16.7 \\
Traditional rulers & 4 & 33.3 \\
Heads of trade unions (market & & \\
and auto-mechanic groups) & & 25 \\
CHEWs & 3 & 16.7 \\
Youth leaders & 2 & $\mathbf{1 0 0}$ \\
Local government administrator & 1 & 50 \\
Total & $\mathbf{1 2}$ & \\
Location & 6 & $\mathbf{1 0 0}$ \\
Enugu North LGA & & \\
Nsukka LGA & & \\
Total & & \\
\hline
\end{tabular}

Data presented in Table 1 indicated more males (83.3\%) than females (16.7\%), which could be attributed to our choice of respondents because community opinion leaders in Nigeria are often males. The nature of our respondents (traditional rulers, trade union leaders, and youth leaders) also implied that many persons aged above 30 years old would be participating in the study. We made efforts to balance respondents across the urban and rural study locations so that we could avoid the experiences of one riding over the other. 
Prince Agwu, Chinweoke Methodius Ugwu, Chidera Florence Eke | ASEAN Journal of Community Engagement | Volume 4, Number 2, 2020

\section{Results and Discussion}

The quotes from respondents are presented in three thematic categories. The first category details the narratives on how communities are involved in the fight against COVID-19 through their opinion leaders. The second examines the efficacy of the mode of communication, and the third proffers suggestions regarding what can be done further.

\subsection{Involvement of grassroots in curbing the spread of COVID-19}

We had to ascertain the involvement of community stakeholders in the charge against COVID-19. We found that some community stakeholders were involved, in the sense that they received directives from the government, but they barely contributed to the formulation of the directives. Communication was also mostly centered around the acquisition and distribution of palliatives to ease lockdown effects and some non-pharmaceuticals to scale up preventive measures against the virus. See supportive quotes below:

"... Since the news about coronavirus around March, the government helped us to procure more than 100 buckets with their stands and kept them at strategic entrances to the market alongside soap and sanitizers... We also distributed the little pandemic palliatives provided by the government. In addition, we were asked to set up the market COVID-19 task force, which we inaugurated, and the government assisted with fumigation ..." (Market leader, Nsukka LGA).

"... The task force, which the government instructed us to set up, moves around the market to ensure that traders and buyers are obeying the protocols. It also enforces the closing time, which is now earlier. I discovered that whenever the traders see the market task force, they will remember and obey the safety protocols ..." (Market leader, Enugu North LGA).

“... Nigerian students were carried along only by the state government that gave us the sum of 2 million naira (\$US 5200) to buy palliatives and distribute to the students, especially to those who were stranded in tertiary institutions in Enugu because of the travel ban, those rendered homeless, and those doing menial jobs to survive as students because COVID-19 distorted their means of livelihood ..." (Youth leader 1, Enugu North LGA).

“... The local government brought palliatives for us to share and they brought them to me as the traditional ruler. The palliatives included beans, rice, tubers of yam, cooking ingredients, and some money. We shared them with everyone, especially the needy ..." (Traditional ruler 2, Nsukka LGA).

One of the respondents complained about their voices not being heard in the formulation of strategies to beat the spread of the virus. To him, a top-bottom approach was employed. See his quote below:

“... The government did their best, but I expected them to ask us what can work for us. We were not called for any meeting to offer suggestions. It is like they know the disease better than us, and because they are the government, we hardly question them. We simply do what we are told like robots ..." (Head of an auto-mechanic group, Nsukka LGA). 
Prince Agwu, Chinweoke Methodius Ugwu, Chidera Florence Eke | ASEAN Journal of Community Engagement | Volume 4, Number 2, 2020

\subsection{Mode of communication and efficacy}

The "how" is as important as the "what" in communication. We investigated if the mode of communicating with the grassroots encouraged community participation in the charge against the virus. We discovered several communication gaps, especially misinformation and exclusion of rural areas. Social and electronic media were mentioned often by respondents as the major modes of communicating about COVID-19. See the supportive quotes below:

“... In the rural areas here, only a few people observe the precautionary measures, especially the social distancing and wearing of face masks. The situation is different from urban areas where people can easily access the media for more knowledge about the virus [...] Some people in rural areas will even try to discourage you, claiming that the virus does not exist ..." (Market leader, Nsukka LGA).

“... We placed flex banners about the preventive measures at strategic points [...] I was equally involved in radio programs where I rightly told the traders that the disease is deadly, and necessary protocols must be observed as I do not want to lose anybody ..." (Market leader, Enugu North LGA).

“... The sensitization process failed to reach those in rural areas [...] I went to an interior village in Enugu with my team, and I was surprised to see that the people lived so normally as they have never heard about the virus. We had to start educating them in the local dialect [...] You cannot blame them. The messages were mainly through text messages, radio, TV, and social media. Most people in rural areas do not have access to these devices. That is why if you visit such areas, they remain as though they are immune to the virus ..." (Youth leader 2, Enugu North LGA).

To fill the communication gap, some people who are poorly educated rely on those that they assume to be well educated for information. The poor system of communicating about the virus alongside distrust in government influences the preventive reactions of citizens.

“... Many people have the wrong notion about the virus. Some feel that the government is creating the virus to loot money; others think that the weather condition and our nature of constantly being exposed to malaria and fever have given us immunity. Persons who are not that educated rely on the educated for the information, and they are misinformed to start thinking that COVID-19 does not exist or that they are naturally immune to the virus. A communication problem exists in our country ..." (CHEW 1, Enugu North LGA).

Some of the participants resented the enforcement processes of security outfits on stay-athome orders and wearing of facemasks. A typical quote can be seen below:

“... The local task force in Enugu usually takes bribes and even while in the process of asking you to put on your facemask, they keep coming close to you and touching you. The police do the same thing. They want to enforce rules, yet they take bribes, which in the process means that money is exchanged using hands, contacts are established, and the virus can spread. Places where the police beat people also exist. Are they immune to the virus? ..." (Head of an auto-mechanic group, Enugu North LGA).

\subsection{The way forward}

Having identified that the gaps in communication to engage communities must have affected community-aggregated efforts against the virus, we asked respondents about their thoughts on what can be done differently. Key strategies they suggested include decentralizing relevant 
Prince Agwu, Chinweoke Methodius Ugwu, Chidera Florence Eke | ASEAN Journal of Community Engagement | Volume 4, Number 2, 2020

agencies, improving the involvement of primary healthcare facilities and their infrastructure, resorting to traditional means of communication, improving the database of Nigerian citizens, and improving trust in government.

“... We need the agencies to be well decentralized. We want to have the face of the Nigeria Centre for Disease Control down to the LGAs. Our primary healthcare facilities are not playing any role. We should be able to have the equipment and training to handle tests and emergencies caused by COVID-19 other than make references and in the process lose the life of the sick person ..." They should carry us along (CHEW 2, Enugu North LGA).

“... Decentralization makes things easy and will be a welcome development. Having an NCDC chairperson in each state will be good. It will make the people believe and trust the process more than someone who is always communicating with us from Abuja (Nigeria's Capital) through text messages ..." (Traditional ruler 1, Nsukka LGA).

“... During elections, the government has a way of reaching the remotest of places. How come they cannot employ that same aggressiveness during a pandemic? Different ways can be used to talk to rural communities because social media, TV, and radio are not that effective in such areas. You can use town criers, speak to them through the representatives of wards or primary healthcare facilities, call them for townhall meetings, speak to them in their indigenous languages, and carry them along just as they (the politicians) always do during elections ..." (Local government administrator, Nsukka LGA).

“... We do not have a solid database. That is why palliatives must be shared and those that are indeed poor benefit nothing. Such poor persons end up feeling that the government does not care about them ..." (Head of an auto-mechanic group, Enugu North LGA).

“... As I previously mentioned, we were not asked what can work for us. We were not invited to discuss the measures. The people were asked nothing. They kept giving us the directives, and we do whatsoever they wish. The government should discuss with us, so that the people themselves can even come up with suggestions on how to handle things. Again, the government should be sincere with the cases and even with the money they spend on such cases, so that people will not think that it is another way to embezzle money because they are already thinking that way ..." (Head of an auto-mechanic group, Nsukka LGA).

Successful efforts against disease outbreaks are a combination of the efforts of the government and communities. The Liberia case is a reference point that communicates how important community efforts are to help address disease outbreaks (Abramowitz et al., 2015). Interfacing with communities and aggregating their supports during the COVID-19 pandemic has been a viable strategy, as community members cultivate the responsibility to stay safe and enforce safety guidelines by themselves (AFENET, 2020). The idea is to promote a "we-feeling" against the virus, which often leads to a speedy reduction in its spread (Zhu \& Cai, 2020). Moreover, the "we-feeling" against the virus can also manifest in sustaining safety protocols long after they have been introduced. Thus, when suboptimal behaviors persist during public health emergencies, there is need to investigate the extent to which the community members have been involved in designing, adapting, and sustaining safety strategies.

Owing to the poor compliance with COVID-19 safety protocols in Nigeria as lamented by the country's Presidential Task Force (Ogundipe \& Olawale, 2020), we investigated the 
Prince Agwu, Chinweoke Methodius Ugwu, Chidera Florence Eke | ASEAN Journal of Community Engagement | Volume 4, Number 2, 2020

effectiveness of community engagements within the country by interfacing with community opinion leaders who are often seen as the face of their communities, as we observed that the government had a way of passing information through them. Our findings showed that community opinion leaders complained about being only information carriers, rather than contributing to framing directives and together with the government, consider what strategy could work for them. Co-producing knowledge is an important element in public health (National Institutes of Health, 2011) but seems less patronized in Nigeria's charge against COVID-19, as revealed by our findings. Respondents were of the view that COVID-19 communication strategies were top-bottom, and never took into consideration their voices and peculiarities. To them, they were at the command of the government, and wished they had the opportunity of expressing their views on how best they can go about the safety strategies, paying attention to the peculiarities of their contexts. Unfortunately, the opportunity of community participation was never presented, which they argued is a chief reason for the utter disregard of government directives at some point.

Our findings reveal that the gap in communication between the people (both in urban and rural areas) and the government caused them to resort to keeping to the safety measures just when they are likely to be punished by some enforcers, and not because it is the right thing to do. This indicates that keeping to safety measures during public health emergencies would not rely totally on law enforcers, despite the important roles they play. It is rather a function of well-tailored information and popular acceptance of strategies by the community. We strongly argue that pretentious and maladaptive behaviours during public health emergencies is a manifestation of being poorly informed, and the lack of voice of the community members in contributing to the rules expected to guide them. Moreover, we discovered that information was skewed for some reasons that bother on the exclusion of rural areas in communication channels, misinformation of the less educated and rural population by the so-called educated and urban residents, and lack of trust in government.

The respondents mentioned that the major communication channels deployed to relay information to most Nigerians include electronic, print, and social media. Access to these communication channels is far less obtainable in most parts of rural Nigeria, and their mechanisms are poorly or not understood by the less or uneducated Nigerians who comprise almost $40 \%$ of the population (National Commission for Mass Literacy, Adult and Nonformal Education, 2018). Approximately 13\% of Nigerians are on social media, with the projection of 
Prince Agwu, Chinweoke Methodius Ugwu, Chidera Florence Eke | ASEAN Journal of Community Engagement | Volume 4, Number 2, 2020

an increase to $19.1 \%$ by 2025 (Statista, 2020). Less than $40 \%$ of Nigerians living in rural areas have access to electricity, whereas close to $50 \%$ of Nigerians are deprived of electricity access (Trading Economics, 2020). Mobile communication stands at almost 84\% but those with smartphones are approximately 20\% (Kemp, 2020; Trading Economics, 2020). These statistics validate the arguments of the respondents that the government or relevant agencies should have deployed traditional means of communication, such as town criers, and engaged the services of Community Health Extension Workers (CHEWs) and community social workers to take the message down to the grassroots. Most respondents reported that the rural areas specifically acted as though the virus was never real, which could be traceable to the amount and quality of information at their disposal, including the pattern through available information reached them.

Public health messaging is as important as the message. The messages must be communicated in an inclusive fashion that respects the peculiarities and dynamics of various population groups. It should be known that what can be obtainable in an urban context, might not be in a rural context. Even within an urban context, there are different population groups, such as the educated versus uneducated, those living in formal settlements versus informal settlements, the rich versus the poor, among others. It is expected that during public health emergencies, each of these groups should have their own tailored messaging pattern, as it will show regards for peculiarities and contexts, which is key to inclusion. No doubts that an effective public health messaging would be vital to eliciting the right behaviors toward curbing the spread of diseases during outbreaks. Therefore, community engagement is not just about co-producing knowledge, but must pay attention to how messages are communicated.

It is often said that the "how" is as important as the "what". So, a breach in communication could hinder participation which is central to community engagement. This is why our PPRR model emphasizes the need to get communication well-tailored to fit several contexts. It rates communication as central to governance, and an important ingredient in galvanizing the inclusion of community members to take up the responsibility of staying safe during a pandemic. Unfortunately, it seems that in the context of Nigeria, the communication element of governance in a pandemic era has been suboptimal, owing to the many cases of citizens disregarding the safety protocols against COVID-19. Our study has therefore shown that the Nigerian government must re-evaluate its risk communication framework through a lens of inclusion and sustainability (citizens carrying on with expected and desired behaviours even 
Prince Agwu, Chinweoke Methodius Ugwu, Chidera Florence Eke | ASEAN Journal of Community Engagement | Volume 4, Number 2, 2020

when the enforcers of the law are no more) to ensure optimal compliance with the laydown safety protocols.

One way that an effective risk communication can be achieved in Nigeria is paying attention to the importance and roles of the primary healthcare, which is the closest source of health service to the grassroots. We discovered a lack of engagement at that level, as respondents from the primary healthcare mentioned that their roles were largely peripheral. It somewhat represents a dearth of provision of healthcare for communities dealing with COVID-19 on the one hand, and an absence of community-centred public health communication on the other. This is because, the primary healthcare is responsible for the sensitization of community members about health concerns, including emerging ones such as COVID-19. Statutorily, health workers at this level of healthcare are expected to conduct community outreach as a way of taking healthcare to the doorsteps of community members. So, if the primary healthcare in Nigeria is faced with weak involvement during a public health emergency as COVID-19, then it means that the communities have been poorly engaged all along which could be implicated in the recent rise of COVID-19 cases and community transmission across Nigeria (NCDC, 2020).

Additionally, the respondents also felt that NCDC is not decentralized and thus is lost in connections at the grassroots. Perhaps, the primary healthcare, if well functional, can be the face of NCDC at the level of communities. This adds to the several clamours that primary healthcare in Nigeria should be well funded, equipped, and trained to rise to occasions of disease outbreaks like COVID-19. Also, given the community development and organisation training social workers receive, deploying them to healthcare institutions, especially the primary healthcare is also needed. Besides, social workers are trained in equity and human welfare, and are poised to ensure that the uniqueness of individuals, groups, and communities are respected at all times. However, it will make sense to equally emphasize public health and pandemic lessons and approaches as part of the educational content for social workers to strengthen their capacities within public health domains (Nnama-Okechukwu et al., 2020; Onalu et al., 2020).

Overall, our findings connect with the PPRR model that we developed and adopted as our conceptual framework. The study participants perceived that persons at the grassroots were not co-opted into the decision framing around containing COVID-19. They rather took directives that often do not consider their contexts and peculiarities. Also, rural areas were not well reached by relevant agencies. Communication is essential in governance process and 
Prince Agwu, Chinweoke Methodius Ugwu, Chidera Florence Eke | ASEAN Journal of Community Engagement | Volume 4, Number 2, 2020

finding efficient and unique ways to communicate information on COVID-19 is an important step in fostering grassroots compliance. Therefore, the non-inclusive process of governance for containing COVID-19 in the study location accounted for their weak participation and response, as findings show many cases of flouting the guidelines for staying safe. References also exist to indicate that the PPRR model, which we feel can otherwise yield an improved compliance of the grassroots and commendable health outcomes during disease outbreaks, was not the case in Nigeria (ACAPS, 2020; Enwereji \& Ezema, 2020).

It is also important that going forward, the government must increase its accountability before citizens, so that they do not consider pandemic responses as fund embezzling strategies for government officials, which can create disbelief and distrust in government affairs (Onwujekwe, Orjiakor, \& Agwu, 2020). The respondents suggested that the accountability of the government can be improved by investing in building a quality database of Nigerians. That way, palliatives can be shared with deserving persons and can equally be tracked. Some monies and palliatives disbursed by the government were mentioned, but data to back the sharing formulae to those who are indeed in need of the items were missing. Trust between government and the people is an important determinant of citizens cultivating the right behaviours capable of containing and curbing disease outbreaks (Dixit et al., 2020; O'Mara-Eves et al., 2015). The respondents highlighted the weak accountability of the security forces who were implicated in taking bribes and melting brutality on them. They felt that the security agencies were neither exemplary in keeping the safety rules nor did they assist in stepping down lessons to the citizens in a civil manner. CLEEN Foundation (2020) documents how security agencies compromised community engagement efforts against COVID-19, including how some of them became infected, but their cases were being shielded from the public. Such an experience likely develops distrust in government and disbelief over the virus.

\section{Conclusion}

Our findings corroborate the PPRR model in community engagement, as they show that to elicit appropriate behaviours from citizens in containing COVID-19 and disease outbreaks, the government must ensure community-focused governance, improve its accountability scores, and foster grassroots-target communication that is as effective as what is obtainable during elections. Doing so can allow them to devise clear means to give communities a sense of voice and participation in proffering solutions and strategies to chart and enforce compliance with 
Prince Agwu, Chinweoke Methodius Ugwu, Chidera Florence Eke | ASEAN Journal of Community Engagement | Volume 4, Number 2, 2020

safety measures against the disease. Our study concludes that community engagement in Nigeria during the COVID-19 pandemic has been poor and that has affected the charge against the virus. We illustrated what the government can do differently to improve community relations and galvanize compliance with safety protocols against COVID-19. Thus, we believe that our findings, including the PPRR model, can improve pandemic responses going forward. Hence, commencing the building of some of these suggestions into the fabrics of the country as COVID-19 persists and in the event of the emergence of future disease outbreaks will make sense.

Finally, our study is limited by only sampling voices of opinion leaders that make a relatively small sample size. Thus, future research can consider expanding the study scope to include other community members. Further studies can also consider focusing on either rural or urban areas to underscore community engagement in different settings.

\section{Acknowledgement}

We thank Professor Obinna Onwujekwe, Professor Uzoma Okoye, and Charles Orjiakor for their contributions to the development of the PPRR model. We are also grateful to the respondents for devoting their time to partake in the study.

\section{Author Contribution}

Prince Agwu conceived of the presented idea. Prince Agwu, Chinweoke Methodius Ugwu, and Chidera Florence Eke developed the theory and performed the computations. Prince Agwu, Chinweoke Methodius Ugwu, and Chidera Florence Eke verified the analytical methods. Prince Agwu supervised the findings of this work. All authors discussed the results and contributed to the final manuscript.

\section{References}

Abramowitz, S., McLean, K., McKune, S., Bardosh, K., Fallah, M., Monger, J., Tehoungue, K., \& Omidian, P. (2015). Community-centered responses to Ebola in Urban Liberia: The view from below. PLoS Neglected Tropical Diseases, 9(4), 1-18. 
Prince Agwu, Chinweoke Methodius Ugwu, Chidera Florence Eke | ASEAN Journal of Community Engagement | Volume 4, Number 2, 2020

ACAPS. (2020). COVID-19 in Nigeria: Vulnerabilities to COVID-19 and containment measures.

https://www.acaps.org/sites/acaps/files/products/files/20200526_acaps_thematic_rep ort_covid19_in_nigeria.pdf

AFENET. (2020). Using community engagement for effective case isolation and contact tracing. http://afenet.net/index.php/news/news/757-using-community-engagement-foreffective-case-isolation-and-contact-tracing

Agwu, P. (2020). Coronavirus: Local community initiative is essential as we ease lockdowns in Nigeria.

https://www.thenigerianvoice.com/news/287698/coronavirus-local-communityinitiative-is-essential-as-we-e.html

Agwu, P., Okoye, U., Ekoh, P., Chukwu, N., Onalu, C., Igwe, I., Onuh, P., Amadi, G., \& Nche, G. (2020). A systematic review of drivers and interventions against sex work migration in Edo State, Nigeria. International Journal of Sociology and Social Policy, 40(7/8), 733764. https://doi.org/10.1108/IJSSP-03-2020-0097

Barker, K., Ling, E., Fallah, M., VanDeBogert, B., Kodl, Y., Macauley, J., Viswanath, K., \& Kruk, M. (2020). Community engagement for health system resilience: evidence from Liberia's Ebola epidemic. Health Policy and Planning, 35(4), 416-423.

https://doi.org/10.1093/heapol/czz174

CLEEN Foundation. (2020). COVID-19: People wear face masks to avoid harrassment by security agents. https://prnigeria.com/2020/07/05/covid-19-face-masks-cleen/

Creswell, J. W. (2013). Qualitative inquiry \& research design: Choosing among the five approaches. SAGE Publications, Inc, Thousand Oaks, California

Dixit, S., Ogundeji, Y., \& Onwujekwe, O. (2020). How well has Nigeria responded to COVID-19? https://brookings.edu/blog/future-development/2020/07/02/how-well-has-nigeriaresponded-to-covid-19/

Ebenso, B., \& Otu, A. (2020). Can Nigeria contain the COVID-19 outbreak using lessons from recent epidemics? The Lancet. https://doi.org/10.1016/S2214-109X(20)30101-7

European Centre for Disease Prevention and Control. (2020). COVID-19 situation update worldwide, as of 8 October 2020.

https://www.ecdc.europa.eu/en/geographical-distribution-2019-ncov-cases 
Prince Agwu, Chinweoke Methodius Ugwu, Chidera Florence Eke | ASEAN Journal of Community Engagement | Volume 4, Number 2, 2020

Enwereji, E., \& Ezema, M. (2020). Addressing the challenges that affect COVID-19 prevention in the rural areas of Abia State, Nigeria. International Journal of Community Medicine and Public Health, 7(10), https://dx.doi.org/10.18203/2394-6040.ijcmph20204345

Kavanagh, M., Erondu, N., Tomori, O., Dzau, V., Okiro, E., Maleche, A., Aniebo, I., Rugege, U., Holmes, C., \& Gostin, L. (2020). Access to lifesaving medical resources for African countries: COVID-19 testing and response, ethic, and politics. Lancet, https://doi.org/10.1016/S0140-6736(20)31093-X

Kemp, S. (2020). Digital 2020: Nigeria. https://datareportal.com/reports/digital-2020-nigeria

National Commission for Mass Literacy, Adult and Non-formal Education. (2018). 38\% of Nigerians are illiterates. https://www.vanguardngr.com/2018/12/38-of-nigerians-areilliterates/

National Institutes of Health. (2011). Community engagement. https://www.atsdr.cdc.gov/communityengagement/pdf/PCE_Report_508_FINAL.pdf NCDC. (2020). COVID-19 in Nigeria. https://covid19.ncdc.gov.ng/

Nelson, E. (2020). Coronavirus in Nigeria: A case for community engagement. https://www.thinkglobalhealth.org/article/coronavirus-nigeria-case-communityengagement

Nnama-Okechukwu, C., Chukwu, N., \& Nkechukwu, C. (2020). COVID-19 in Nigeria: Knowledge and compliance with preventive measures. Social Work in Public Health, 35(7), 590602. https://doi.org/10.1080/19371918.2020.1806985

O’Mara-Eves, A., Brunton, G., Oliver, S., Kavanagh, J., Jamal, F., \& Thomas, J. (2012). Community engagement in public health interventions to reduce health inequalities: mapping the evidence against policy objectives. The Lancet, 380(59),

https://doi.org/10.1016/S0140-6736(13)60415-8

O'Mara-Eves, A., Brunton, G., Oliver, S., Kavanagh, J., Jamal, F., \& Thomas, J. (2015). The effectiveness of community engagement in public health interventions for disadvantaged groups: a meta-analysis. BMC Public Health, 15(129).

https://doi.org/10.1186/s12889-015-1352-y

Ogbonna, A. (2018, February 6). Buhari declines assent to three bills passed by NASS. Vanguard. https://www.vanguardngr.com/2018/02/buhari-declinesassent-three-bills-passednass/ 
Prince Agwu, Chinweoke Methodius Ugwu, Chidera Florence Eke | ASEAN Journal of Community Engagement | Volume 4, Number 2, 2020

Ogundipe, S., \& Olawale, G. (2020, October 9). COVID-19: Nigeria may record surge in casesPTF. Vanguard.

https://www.vanguardngr.com/2020/10/covid-19-nigeria-may-record-surge-in-casesptf/

Okwor, L. (2020, July 5). Enugu COVID-19 surge: It's time we took responsibility. https://www.msn.com/en-za/news/other/enugu-covid-19-surge-it-e2-80-99s-time-wetook-responsibility/ar-BB16lyHa

Onalu, C., Chukwu, N., \& Okoye, U. (2020). COVID-19 response and social work education in Nigeria: matters arising. Social Work Education, 39(8), 1037-1047.

https://doi.org/10.1080/02615479.2020.1825663

Onwujekwe, O., Orjiakor, C., \& Agwu, P. (2020). Coronavirus: corruption in health care could get in the way of Nigeria's response.

https://theconversation.com/coronavirus-corruption-in-health-care-could-get-in-theway-of-nigerias-response-136913

Onyishi, J., Ejike-Alieji, E., Ajaero, C., Mbaegbu, C., Ezeibe, C, Onyebueke, U., Mbah, P., \& Nzeadibe, C. (2020). COVID-19 pandemic and informal urban governance in Africa: A political economy perspective. Journal of Asian and African Studies.

https://doi.org/10.1177\%2F0021909620960163

Padgett, D. K. (2008). Qualitative methods in social work research (2nd ed). California: Thousand Oaks.

Ramsbottom, A., O’Brien, E., Ciotti, L., \& Takacs, J. (2017). Enablers and barriers to community engagement in public health emergency preparedness: A literature review. Journal of Community Health, 43(3), 1-9. https://link.springer.com/article/10.1007/s10900-0170415-7

Statista. (2020). Social network user penetration in Nigeria from 2017-2025. https://www.statista.com/statistics/972921/social-network-penetration-innigeria/\#: :text=In\%202019\%2C\%2012.2\%20percent\%20of,to\%2019.1\%20percent\%2 0in\%202025 
Prince Agwu, Chinweoke Methodius Ugwu, Chidera Florence Eke | ASEAN Journal of Community Engagement | Volume 4, Number 2, 2020

The Economic Times. (2020). Counter misinformation, superstition on coronavirus: PM to social workers. https://economictimes.indiatimes.com/news/politics-and-nation/countermisinformation-superstition-on-coronavirus-pm-to-socialworkers/articleshow/74893933.cms

Trading Economics. (2020). Nigeria-Access to electricity, rural (\% of rural population). https://tradingeconomics.com/nigeria/access-to-electricity-rural-percent-of-ruralpopulation-wbdata.html\#: :text=Access $\% 20$ to\%20electricity\%2C\%20rural\%20(\%25\%20of\%20rural \%20population)\%20in\%20Nigeria,compiled\%20from\%20officially\%20recognized $\% 20$ s ources

van Niekerk, L., Ongkeko, A., Hounsell, R., Msiska, B., Mathanga D., Mothe, J., Juban, N., Awor, P., \& Balabanova, D. (2020). Crowdsourcing to identify social innovation initiatives in health in low- and middle-income countries. Infectious Diseases of Poverty, 9(138), 1-12. https://doi.org/10.1186/s40249-020-00751-x

Zhu, J., \& Cai, Y. (2020). Engaging the communities in Wuhan, China during the Covid-19 outbreak. Global Health Research and Policy, 5(35), 1-4. https://doi.org/10.1186/s41256020-00162-3 